\title{
Experimental Behaviour of Seawater Concrete with Copper Slag
}

\author{
P.Madona Kaviarasi, S.Sivakumar
}

\begin{abstract}
Marine concrete structures are subjected to very severe exposure conditions and their durability is directly related to the quality of concrete used in the construction due to the salinity present in water. The present study intends to evaluate the strength and bonding property of copper slag in sea water concrete $(S W C)$ and tap water concrete $(T P C)$. In total the mixes were cast with $25 \%$ using copper slag as a substitution for fine aggregate at constant w/c 0.4 for M40 mix grade. The various tests conducted on different concrete mixes included fresh properties, compressive strength, split tensile strength, young's modulus, flexural and bond strength. Results showed that fresh properties enhanced with increment in copper slag substitution. The experimental trails were carried out for higher strength and durability. The projected mix design method was found to be agreeable for producing concrete with fine aggregates having different properties. The $\mathrm{pH}$ of sea water used fluctuates between 6.4 to 8.10. The specimens were casted for various sea water having different $\mathrm{pH}$ the strength was compared with the control specimen.
\end{abstract} pH.

Keywords:- copper slag, salinity, strength, durability, and

\section{INTRODUCTION}

Marine environment requires the use of a very low permeability concrete for the construction of durable concrete structures. Mix compositions as well as the binder material type manipulate the permeability of sea water concrete. The use of blended cements with pozzolanic materials is well-known to reduce the permeability. In order to withstand the tremendously intimidating environment, compressive strength of concrete above $40 \mathrm{MPa}$ is essential, although this level of strength may not be required from the various loading. High-strength concretes contain a relatively high binder material content, a superplasticiser, and very low water content to achieve the high strength when water to binder ratio below 0.38 , by volume. They are able of achieving an alternating capillary pore structure and low permeability within a few days of cement hydration. Copper slag also known as Ferro sand is generated during pyrometallurgical process involved in production of copper from copper manufacturing. For every ton of metal production of copper approximately 1.8-2.2 tons of slag is produced. The material having properties related to river sand and it can be utilized as a replacement of sand in concrete during construction. Presently, universal, about 33 million tonnes of slag is generated every year with India causative 6 million tonnes. Some applications, wherein slag has already been accepted world-wide, are cement and concrete manufacturing, filling material, river embankment, ballast

Revised Manuscript Received on April 12, 2019.

P.Madona Kaviarasi, PG Scholar, Dept.Civil Engineering, PSNA College of Engineering and Technology, Dindigul, T.N, India.

S.Sivakumar, Professor, Dept.Civil Engineering, PSNA College of Engineering and Technology, Dindigul, T.N, India. material, abrasive, pavement blocks, road and roofing construction, granules, glass and tiles making. This research has concluded that copper slag is non-leachable, and nonhazardous. Various researchers have found that the possible use of copper slag as fine and coarse aggregates in concrete and its effects on the different mechanical and long-term properties of concrete. With several benefits of using copper slag as fine and coarse aggregates, some harmful effects such as delaying of the setting time, especially when only copper slag has been used as fine aggregate have also been reported. Copper slag has been used as abrasive tools, roofing granules, cutting tools, tiles, road construction as base material, rail road ballast and nowadays in concrete industry as partial replacement of cement and fine aggregate. Copper slag has high iron content and has been suggested to be used in cement clinker making; the performance of the cement using copper slag in the clinker has been reported to have better properties than the cement that used limestone and clay. Several researchers have reported the properties of copper slag when used as a partial replacement of cement and have found that it plays important role in the formation of hydration products. Some researchers reported that copper slag when used as fine aggregate reduces the shrinkage of concrete and enhanced the mechanical and long-term properties concrete. It has been reported by many researchers that the compressive and flexural strength of concrete were also better when copper slag was replaced with fine aggregate. This paper deals with the properties of concrete with copper slag as replacement of fine aggregate for concrete that can be used in marine applications.

Concrete exposed to sea water will be subjected to wetting by an aqueous solution containing principally dissolved $\mathrm{NaCl}$ and $\mathrm{MgSo}_{4}$ sodium chloride and magnesium sulfate. The oceans contain on the average about 35 parts per four thousand (3.5 percent) of dissolved salts. The major cations, $\mathrm{Ca}++, \mathrm{Mg}++\mathrm{Na}+$, and $\mathrm{K}+$, exist in sea water largely as uncomplexed species. The major anions include $\mathrm{C1}^{-}$, which is also not strongly complexed, and $\mathbf{C O}_{3}, \mathrm{HCo}_{3}{ }^{-}$, and $\mathrm{So}_{4}$, which are expressed as milligrams per liter of sea water. The sea water has a total salinity of about $3.5 \%(78 \%$ of the dissolved solids being $\mathrm{NaCl}$ and $15 \% \mathrm{MgCl}_{2}$ and $\mathrm{MgSO}_{4}$ ), and produces a small higher early strength but a lower long-term strength. Sea water is a complex solution of many salts containing living matter; silt suspended, dissolved gases and decomposing natural material. The major chemical constituents of seawater are the ions of chloride, sodium, magnesium, calcium and potassium. Sea 
water can be said to have a solution containing a large number of elements in various proportions. Water containing large quantities of chlorides tends to cause determined dampness and surface efflorescence. Such sea water should, therefore not be used where appearance is important. The $\mathrm{pH}$ value of seawater varies between 7.4 and 8.4. Corrosion of the reinforcing steel occurs below a $\mathrm{pH}$ of 11. Therefore, in cases where concrete is subjected to a highly severe environment, then the cement must supply alkalinity.

\section{EXPERIMENTALMETHOD \& RESULTS}

\section{Materials and methods:}

Cement, in general, adhesive substances all kinds of the binding materials used in building construction. It is finely ground powders that, when mixed with water. Setting and hardening result from hydration, which is a chemical mixture of the cement compounds with water that yields submicroscopic crystals or a gel-like material with a high surface area. Portland cement consists essentially of compounds of lime (calcium oxide, $\mathrm{CaO}$ ) mixed with silica (silicon dioxide, $\mathrm{SiO}_{2}$ ) and alumina (aluminum oxide, $\mathrm{Al}_{2} \mathrm{O}_{3}$ ). The lime is obtained from a raw material, and the other oxides are derived from a clayey material. The commonest calcareous raw materials are limestone and chalk, but others, such as coral or shell deposits, also are used. Another raw material is blastfurnace slag, which consists mainly of lime, silica, and alumina and is mixed with a calcareous material of high lime content. The magnesia (magnesium oxide, $\mathrm{MgO}$ ) content of raw materials must be low because the permissible limit in Portland cement is 4 to 5 percent. Another essential raw material is gypsum, some 5 percent of which is added to the burned cement clinker during grinding to control the setting time of the cement.

Table 1 Composition limits of Portland cement

\begin{tabular}{|c|c|}
\hline Ingredient & Percent, content \\
\hline $\mathrm{CaO}$ (Lime) & $60-67$ \\
\hline $\mathrm{SiO} 2$ (Silica) & $17-25$ \\
\hline $\mathrm{Al} 2 \mathrm{O} 3$ (Alumina) & $3-8$ \\
\hline Fe2O3 (Iron Oxide) & $0.5-0.6$ \\
\hline $\mathrm{MgO}$ (Magnesia) & $0.1-0.4$ \\
\hline Alkalies & $0.4-1.3$ \\
\hline Sulphur & 1.3 \\
\hline
\end{tabular}

OPC 53 grade (Ultratech) was used. The specific gravity of cement was 3.22. The consistency limit of cement was $32 \%$. Initial and final setting time of cement was 45 minutes and 10 hours.

Table 2 Properties of Ordinary Portland cement

\begin{tabular}{|c|c|}
\hline Test & Results \\
\hline Specific gravity & 3.19 \\
\hline Standard consistency & $32 \%$ \\
\hline Initial setting time & 30 minutes \\
\hline Final setting time & 4.25 hours \\
\hline
\end{tabular}

Fine aggregates for the most part comprise of natural sand or compacted stone with most particles passing through a $9.5 \mathrm{~mm}$ sieve. Fine aggregates for the most part comprise of natural sand or crushed stone with most particles passing through a $3 / 8$-inch sieve. Fine aggregate is characteristic sand which has been washed and sieved to evacuate particles bigger than $5 \mathrm{~mm}$. The second most regular kind of sand is calcium carbonate, for instance, aragonite, which has for the most part been made, over the past half billion years, by different types of life, similar to coral and shellfish. For instance, it is the essential types of sand obvious in regions where reefs have commanded the biological community for many years like the Caribbean. The properties of fine aggregates are shown in Table 3.

Table 3 Properties of fine aggregate

\begin{tabular}{|c|c|}
\hline Test & Results \\
\hline Specific gravity & 2.3 \\
\hline Fineness modulus & 3.75 \\
\hline Bulk density & $1469 \mathrm{~kg} / \mathrm{m}^{3}$ \\
\hline
\end{tabular}

Aggregates consisting of materials that can react with alkalis in cement and cause excessive expansion, cracking and deterioration of concrete mix should never be used. Therefore it is required to test aggregates to know whether there is presence of any such constituents in aggregate or not.

Table 4 Properties of coarse aggregate

\begin{tabular}{|c|c|}
\hline Test & Results \\
\hline Specific gravity & 2.65 \\
\hline Water Absorption & $0.1 \%$ \\
\hline
\end{tabular}

Copper slag is an industrial by-product material produced from the process of manufacturing copper. The process of extracting copper from copper ore varies according to the type of ore and the desired purity of the final product. Each process consists of several steps in which unwanted materials are removed, physically or chemically, and the concentration of copper is progressively increased. Once the waste materials have been physically removed from the ore, the remaining copper concentrate must undergo several chemical reactions to remove the iron and sulphur. This process is called smelting. The recovery of sulphuric acid from the copper smelting process not only provides a profitable by-product, but also significantly reduces the air pollution caused by the furnace exhaust. Copper slag (CS) is a waste product which comes out from the smelting process.

Table 5 Properties of copper slag

\begin{tabular}{|c|c|}
\hline Test & Results \\
\hline Specific gravity & 3.37 \\
\hline Fineness modulus & 3.84 \\
\hline Water Absorption & $0.3 \%$ \\
\hline
\end{tabular}

Seawater also contains $\mathrm{Mg}^{2+}$ and $\mathrm{SO}_{4}{ }^{2-}$ about 1400 and $2700 \mathrm{mg} / \mathrm{lit}$ respectively. The $\mathrm{pH}$ of seawater fluctuates 
between 7.5 and 8.4. The average $\mathrm{pH}$ is taken about 8.2. Seawater also contains some amount of $\mathrm{CO}_{2}$. If higher concentration of $\mathrm{CO}_{2}$ dissolved in seawater then the $\mathrm{pH}$ may decrease below 7.5. In this paper the various sea waters were used the $\mathrm{pH}$ were tabulated below.

Table $6 \mathrm{pH}$ of sea water

\begin{tabular}{|c|c|}
\hline Place & $\mathrm{pH}$ \\
\hline Rameshwaram & 6.4 \\
\hline Chennai & 7.28 \\
\hline Kerala & 8.10 \\
\hline
\end{tabular}

\section{PROPORTIONS AND MIX}

\section{DESIGN:}

The various mix proportions are studied with the replacement of copper slag in fine aggregate was $25 \%$ with M40 grade of concrete. The ratio of M40 grade was 1: 1.68: 2.24 with the w/c ratio 0.4 . Concrete mixtures with various proportions of copper slag used as a partial for fine aggregates were prepared in order to investigate the effect of copper slag substitution on the strength and durability of normal concrete. Two concrete mixtures were prepared with different proportions of copper slag. The proportions by volume of copper slag added to concrete mixtures were as follows: $0 \%$ (for the control mix), $25 \%$. The control mixture (with $0 \%$ copper slag and $100 \%$ sand) was designed to have a target 28 day compressive strength of $48 \mathrm{~N} / \mathrm{mm}^{2}$, using a water-cement ratio of 0.4 .

To determine the compressive strength and bond strength of concrete, eight cubes $(150 \mathrm{~mm} \times 150 \mathrm{~mm} \times 150 \mathrm{~mm})$ were cast for each mixture, and three samples were tested after 28and 56 days of curing. Six cylinders $150 \mathrm{~mm}$ diameter by $300 \mathrm{~mm}$ height cylinders were prepared for each mixture to determine the tensile strength and young's modulus of concrete. They were tested after 56 days of curing.

Also, to determine the flexural strength for each mixture, three $100 \mathrm{~mm} \times 100 \mathrm{~mm} \times 500 \mathrm{~mm}$ prisms were cast and tested after 28 and 56 days of curing. To evaluate the durability of concrete mixtures, three $150 \mathrm{~mm} \times 150 \mathrm{~mm}$ $\times 150 \mathrm{~mm}$ cubes were prepared to determine surface absorption after 28 and 56 days of curing. The sea water is used for both mixing and curing of concrete mixtures.

Table 7 Mix proportions

\begin{tabular}{|c|c|c|}
\hline S.No & pH of water & Mix proportions \\
\hline 1 & normal & - \\
\hline 2 & 6.4 & $75 \%$ of FA+ $25 \%$ of CS \\
\hline 3 & 7.28 & $75 \%$ of FA+ $25 \%$ of CS \\
\hline 4 & 8.10 & $75 \%$ of FA+ $25 \%$ of CS \\
\hline
\end{tabular}

\section{TEST TO BE CARRIED}

\section{Compression test}

The compressive strength test was exeuted according to ASTM C109-16a. Mortar (1:3) cubes of size $70.6 \mathrm{~mm} \times$ $70.6 \mathrm{~mm} \times 70.6 \mathrm{~mm}$ were cast with various blend extents containing DT and RT. Following 24 hours the cast specimens were demoulded and submerged in water for relieving. Following 28 days of relieving, the cubes are tested in the universal-testing machine of 40 tones limit. The compressive strength was determined from the following equation:fck $\left(\mathrm{N} / \mathrm{mm}^{2}\right)=$ Ultimate load $(\mathrm{N}) /$ Area of the specimen $\left(\mathrm{mm}^{2}\right)$

\section{Split tensile test}

The split tensile test was completed according to ASTM C496-90. Mortar cylinders of size $150 \mathrm{~mm}$ dia and $300 \mathrm{~mm}$ height were cast utilizing different sorts of the blend containing OPC with DT and RT. Amid casting, the moulds were compacted utilizing table vibrator. The cast specimens were demoulded after 24 hours and restored in water for 28 days. After the relieving period was over the specimens were tested in the universal testing machine (UTM) of 40 tones limit.

Split Tensile strength test was calculated using the formula:

$\mathrm{Fsp}=2 \mathrm{P} / \pi \mathrm{dl}(\mathrm{N} / \mathrm{mm} 2)$

where $\mathrm{P}=$ load at failure $(\mathrm{N})$; $\mathrm{d}=$ diameter of the specimen $(\mathrm{mm})$ and $\mathrm{l}=$ length of the specimen $(\mathrm{mm})$.

\section{Flexural strength}

The flexural test was excuted according to ASTM C34814. Mortar slab of size $1300 \mathrm{~mm} \times 500 \mathrm{~mm} \times 60 \mathrm{~mm}$ size were cast with the distinctive blend of blend containing OPC, DT and, RT. The cast specimens were kept in water for relieving after $24 \mathrm{~h}$. After the predefined restoring period, the specimens were exposed to flexural test by applying central point load in a universal testing machine of 40 tones limit.

\section{Bond strength}

Bond stress is calculated as average stress between the reinforcing bar and the surrounding concrete along the embedded length of the bar. In general, the bond stress corresponding to the maximum pull out load can be regarded as the bond strength or the ultimate bond. The criterion of ultimate bond strength is characterized by its clear definition and simplicity in bond strength interpretation. The Contact length is $5 \mathrm{~cm}$ between steel and concrete. The three Numbers $(8,10 \& 12 \mathrm{~mm})$ of steel bars used. Theoretical bond strengths using the formula as per BS $8110 . \mathrm{fbu}=\beta(\mathrm{fcu})^{0.5}$

For uniform bond, the bond stress was computed using formula $\tau=\mathrm{P} /$ (л $\mathrm{d} 1$ ), where $\mathrm{P}$ is load [N], 1 embedded length $[\mathrm{m}]$ and diameter $[\mathrm{m}]$ of the bar.

\section{Young's modulus}

The higher the elastic modulus means the concrete can withstand higher stress but the concrete will become brittle and sooner cracks will appear. Low elastic modulus indicates that it will bend and deform very easily. High elastic modulus at early ages will result in a higher potential for cracking. This is due to high stress produced due to even low strain. Strain can arise from causes other than applied stress like shrinkage. Shrinking and thermal activity can cause very low stress, but due to high elastic modulus, the corresponding stress is high. 
Young's modulus $(\mathrm{E})=$ linear stress/ linear strain

Linear stress $=$ Force/area $=$ F/A

Linear strain $=$ Change in length $/$ original length $=\Delta \mathrm{L} / \mathrm{L}$

Therefore, Young's Modulus $(\mathrm{E})=(\mathrm{F} / \mathrm{A}) /(\Delta \mathrm{L} / \mathrm{L})=\mathrm{FL} /$ $\mathrm{A} \Delta \mathrm{L}$

\section{RESULTS AND DISCUSSIONS}

We suggest that you use a text box to insert a graphic (which is ideally a 300 dpi TIFF or EPS file, with all fonts embedded) because, in an MSW document, this method is somewhat more stable than directly inserting a picture.

To have non-visible rules on your frame, use the MSWord "Format" pull-down menu, select Text Box > Colors and Lines to choose No Fill and No Line

\section{REFERENCES}

1. Tarek Uddin Mohammed and Hidenori Hamada (2004), 'Performance of seawater-mixed concrete in the tidal environment', Cement and Concrete Research.

2. Falah M. Wegian (2010), 'Effect of seawater for mixing and curing on structural concrete', The IES Journal Part A: Civil \& Structural Engineering Pp 235-243.

3. Khalifa S. Al-Jabriand Abdullah H. Al-Saidy (2011), 'Effect of copper slag as a fine aggregate on the properties of cement mortars and concrete', construction and Building Materials pp 933-938.

4. S.A. Barbhuiya and P.A.M. Basheer (2011), 'Effects of seawater-neutralised bauxite refinery residue on properties of concrete', Cement \& Concrete Composites pp 668-679.

5. Mohamed Alwaeli (2013), 'Application of granulated leadzinc slag in concrete as an opportunity to save natural resources', Radiation Physics and Chemistry pp 54-60.

6. Preeti Tiwari and Rajiv Chandak (2014), 'Effect of Salt Water on Compressive Strength of Concrete', International Journal of Engineering Research and Applications pp 38-42.

7. Qiu Li and Haining Geng (2015), 'Chloride resistance of concrete with metakaoli addition and seawater mixing: A comparative study', construction and Building Materials pp 184-192.

8. Sumathy Raju and Brindha Dharmar (2015), 'Mechanical Properties of concrete with Copper Slag and Fly Ash by DT and NDT', Periodica Polytechnica Civil Engineering

9. M.V.PATIL (2015), 'Properties and effects of copper slag in concrete', International Journal of Advances in Mechanical and Civil Engineering. 